\title{
QUALITY AND SAFETY MANAGEMENT SYSTEMS: J OINT ACTION FOR CERTIFICATION OF SMALL FIRMS IN AN INDUSTRIAL CLUSTER IN BRAZIL
}

\author{
M.C. Gerolamo ${ }^{1 *}$, L.C.R. Carpinetti ${ }^{2}$, G.A. Vitoreli ${ }^{3}$, J .E. Sordan ${ }^{4}$ \& C.H.B Lima ${ }^{5}$ \\ Department of Production Engineering \\ Sao Carlos School of Engineering \\ The University of Sao Paulo, Brazil \\ ${ }^{1}$ gerolamo@sc.usp.br, ${ }^{2}$ carpinet@sc.usp.br, ${ }^{3}$ gislaineavitoreli@gmail.com, \\ 4julianosordan@yahoo.com.br, ${ }^{5}$ carlos.bertucci@gmail.com
}

\begin{abstract}
This paper presents and discusses a proposal for joint action among small firms in an industrial cluster in Brazil for the certification of quality and safety management systems. It proposes a management system model, the implementation process, and periodic auditing. It is the result of an action-research project developed in a metal-mechanical cluster. Its originality lies mainly in the proposal for a joint action programme for the certification of companies, led by the cluster governance agency, to increase the collective efficiency of a cluster. Despite the obstacles encountered, this proposal can help to reduce the difficulties faced by small businesses in implementing and maintaining management systems, and in the long run to foster a culture of quality and safety management. It also contributes to joint actions within the cluster. The challenge faced by the cluster governance agency is to sustain the certification programme in the long term.
\end{abstract}

\section{OPSOMMING}

'n Voorstel vir die samewerking van klein industriële firmas in Brasilië met die doel om gehalte- en veiligheidstelsels te sertifiseer word voorgestel en bespreek. 'n Bestuurstelselmodel, die implementeringsproses en 'n periodieke ouditeurstelsel word voorgestel. Dit is die resultaat van ' $n$ aksienavorsingsprojek wat in ' $n$ metaalmeganiesegroep ontwikkel is. Die oorspronklikheid in dié benadering is hoofsaaklik in die voorstel vir samewerking van firmas vir sertifisering doeleindes. Ten spyte van die struikelblokke vergemaklik die voorstel die hantering van probleme ervaar deur klein firmas wanneer hulle bestuurstelsels implementeer en onderhou. Op die lang termyn vestig dit 'n kultuur van gehalte- en veiligheidsbestuur. 


\section{$1 \quad$ INTRODUCTION}

Increasingly, companies are seeking to implement management systems as a way to improve stakeholder satisfaction, reduce inefficiencies, or keep up with market demands. According to a survey conducted by the International Organisation for Standardization, by the end of 2011 there were over one million ISO 9001 certificates globally. As for ISO 14001, the number of certifications almost reached the mark of 300,000 [1]. Several studies worldwide show the positive impacts of implementing ISO 9001 quality management systems [2, 3 , 4]. The performance benefits of implementing occupational health and safety management systems (OHSAS 18001) are also well-discussed in the literature $[5,6]$. The number of OHSAS certifications is not so impressive - about 55,000 in 2009 - but this figure reflects a $70 \%$ increase over the figures recorded in 2007 [7]. The benefits are addressed in a later section of this article.

In this scenario, to comply with diverse normative management system requirements, integrated management systems (IMS) have been adopted by companies as an effective approach to align and integrate the normative requirements of different certification schemes into a single management system. The benefits of integrating management systems are well discussed by Wilkinson and Dale [8], Zutshi and Sohal [9], and Jorgensen et al. [10]. Models and processes for integration are presented, for example, by Zeng, Shi and Lou [11] and J onker and Karapetrovic [12].

Although approaches to the implementation of management systems are generally valid regardless of company size, small companies may have difficulties in implementing such systems through lack of resources, poor organisational ablity to manage quality and other requirements, and so on. Poksinska et al. [13] discussed some lost opportunities, benefits, and influencing factors in implementing ISO 9001 in small organisations. It is therefore a theme in which collaboration, joint action, and the sharing of knowledge between companies in a cluster or network - particularly small companies - can be generally beneficial. Brand et al. [14], for example, proposed a framework to network small South African enterprises for sustainability. Considering the advantage of agglomeration, Turner and O'Neill [15] analysed the implementation of the ISO14001 in the Durban automotive cluster.

Researchers, government bodies, and practitioners in general have been giving growing attention to cooperation networks and industrial clustering, due to the competitive advantage and regional development they enable $[16,17,18,19]$. Clusters are geographic concentrations of interconnected companies, specialised suppliers, service providers, firms in related industries, and associated institutions (e.g., universities, standard agencies, trade associations) in a particular field that compete but also cooperate [16]. Clustered companies - especially small companies - can benefit greatly from external economies, collaboration, joint action, and shared knowledge [20, 21, 22, 23].

Collaboration between companies in a cluster, particularly of SMEs, can often be beneficial in implementing management systems. Thus this paper propooses a joint action programme for certification in managing quality and safety to help companies within the cluster, especially SMEs, to gain competence in managing quality and safety, in reducing risks and the costs of lost quality, and in improving customer satisfaction. Due the main priorities, and also due to limited resources, the project focused first on quality and safety systems; an environmental management system was left for implementation at a later date. The proposal is the outcome of an action research project carried out in a metal-mechanicalal cluster of equipment manufacturers in the State of São Paulo, Brazil. It includes the integrated management system criteria and the process for system implementation and periodic auditing. The research project was carried out by the authors of this paper in collaboration with the cluster governance agency and representatives of the companies involved with the project. 


\section{LITERATURE REVIEW}

\subsection{A note on ISO9001 and OHSAS18001}

ISO9001:2008 [24, p.1] is the international quality system standard. It specifies requirements for a quality management system where an organisation: (i) "needs to demonstrate its ability to consistently provide product that meets customer and applicable statutory and regulatory requirements", and (ii) "aims to enhance customer satisfaction through the effective application of the system, including processes for continual improvement of the system and the assurance of conformity to customer and applicable statutory and regulatory requirements". Since the 2000 edition of ISO 9001, the requirements for quality management focus not only on the activities of product realisation, but also require evidence of the following:

- Management of resources, especially human resources, essential to manage customer requirements in compliance with the product realisation process;

- Senior management commitment to the development, implementation, and continuous improvement of the quality management system;

- Measurement, analysis and improvement of the quality system's effectiveness, by auditing the system; and senior management's critical analysis of product, process, customer satisfaction feedback, and planning and implementation of actions for improvement.

Implementing a quality system not only helps a company to meet customer needs; it also helps to avoid extra costs due to scrapping, re-working, and other sorts of inefficiencies $[25,26,27]$.

The widespread application and evolution of quality management systems has led to the development of other management systems, as in the case of the occupational health and safety assessment series. The OHSAS18001:2007 standard [28] presents the requirements of an occupational health and safety management system, whose main objective is to enable companies to prevent work-related human injury and ill-health. The main system requirements are concerned with establishing, implementing, and maintaining procedures for hazard identification, risk assessment, and determination of necessary controls. Despite the difference between the structure of topics in which the requirements of IS09001:2008 and OHSAS18001:2007 are organised (the structure of OHSAS18001 is based on the PDCA Plan-Do-Check-Act - method, similar to the ISO14001:2004 [29]), the correspondence of their respective requirements is clearly identified in Annexure A of OHSAS18001:2007.

\subsection{Integration of management systems (IMS)}

In management, the concept of integration usually refers to the idea of alignment and unity of action between interdependent activities [30]. In general, the literature on integration distinguishes two levels of integration: alignment, in which similarities of the standards are used to structure the system, but separate procedures for each standard are maintained; and integration, in which full integration of relevant procedures and instructions is implemented $[9,29]$.

Another important aspect is that the implementation of integrated management systems usually takes place in either of the following forms: (a) when the company has a certified management system (most commonly a quality system) and wishes to implement and integrate another system; or (b) when the company plans to implement an integrated management system afresh. As a consequence, the integration of management systems such as ISO 9001, ISO 14001, and OHSAS 18001 has been carried out in different ways [11]. For example, J orgensen et al. [10] propose three different levels of management system integration: a first lower level with increased compatibility between parallel systems; a middle level with coordination and coherent generic processes, with focus on tasks in the management cycle; and an upper level of integration characterised by an organisational 
culture of learning, continuous improvements of performance, and stakeholder involvement related to internal and external challenges.

J onker and Karapetrovic [12] propose a model for system integration based on three main elements of a generic management system: processes, resources, and goals. Zeng et al. [11] propose what they call a synergetic model of integration by defining three levels of integration. They argue that integration of procedures, work instructions, and records (lower level) depends on an integration related to resources and structural and cultural elements. These two levels of integration, in turn, depend on the integration of strategies, objectives, and planning (upper level). Labodova [31] proposes a method for the direct integration of management systems, consisting of seven steps and the use of a risk analysis matrix.

In summary, the literature reviewed suggests that there is no single path for system integration, and that it involves aligning and consolidating objectives, policies, procedures, resource management, and critical review.

\subsection{Benefits and difficulties of implementing management systems}

Many studies in the literature discuss the benefits and difficulties of implementing managing systems, particularly ISO 9001. Martínez-Costa et al. [32], in an empirical study of Spanish companies, found that certified companies performed better than non-certified companies on the internal performance results (product costs, fast delivery, flexibility, and cycle time); but certified companies did not do better than non-certified companies on the external performance results (manufacturing quality, design quality, customer satisfaction, market share, employee satisfaction). Casadesus and Karapetrovic [33, 34, 35, 36] have done a series of empirical studies, also in Spain, on the benefits and costs of ISO9001:2000 compared with its previous edition, ISO9001/2/3:1994. Although the perception of the benefits obtained from ISO9001:2000 has decreased (in comparison with its previous edition) in all investigated criteria, a large majority of companies acknowledged a significantly positive impact through decreasing nonconformities and improving supplier relationships (operational results), improving customer satisfaction and decreasing the complaints (customer focus), improving health and security at work, and team participation including a suggestion system (workers' dimension).

These findings are in line with other studies reported by Singh et al. [37] and Chang and Lo [38]. However, one could interpret Casadesus and Karapetrovic [34] as follows: in only seven (those mentioned above) of the 18 types of benefits, the percentage of companies acknowledging a positive impact was greater than the percentage of companies reporting an indifferent impact or acknowledging a unfavourable impact. That is, in 11 of the 18 types of benefits, the number of companies reporting indifference or a negative impact was greater than the companies reporting a positive impact. For example, concerning financial criteria, Lima et al. [39] found no significant difference in performance level between ISO 9000 registered and non-registered companies in Brazil. Casadesus and Karapetrovic also pointed out in their studies that only around 30 to 40 per cent found any benefit in financial results such as increasing sales, return on investment, and market share. On the other hand, Benner and Veloso [40, p.622] argue that "the stock market value of a firm appears to increase consistently with ISO 9000 certification, suggesting investors expect a higher stream of future profits for adopters than for the nonadopters. This may reflect stockholder expectations arising from the increased legitimacy resulting from ISO 9000 adoption, regardless of whether or not a given firm will realize these expected benefits". Thus it is possible conclude that implementing ISO 9000 has certain benefits, but that it is not a panacea.

Similar results were obtained in studies about the impact of managing occupational health and safety $(\mathrm{OH} \& S)$ on a company's performance. Muniz et al. [5] (2009), based on the results of a survey with companies in Spain, concluded that a safety management system has a direct, positive, and statistically significant influence on safety performance, competitiveness performance, and economic-financial performance. Botanni et al. [6] 
surveyed several health and safety management topics, and concluded that there are significant differences in performance between safety management system adopters and non-adopters. Other studies show the feasibility of implementing integrated quality and $\mathrm{OH} \& \mathrm{~S}$ systems $[41,42]$.

Although many studies confirm the benefits of implementing management systems such as ISO9001 or OHSAS18001, there are cases where problems in implementation and maintenance reduce the potential benefits of management systems or even have a negative impact on performance [37]. Among the many reasons for poor results, there is a consensus about some critical factors such as top management's commitment, the involvement and training of the workforce, cross-functional teams, sustaining internal audits, management review, and corrective actions [27, 37, 38, 43, 44]. An empirical study conducted by Briscoe et al. [43] involving American and Canadian small businesses concluded that small companies can successfully implement ISO9001 certification and benefit from it if they establish a quality culture. On top of that, small companies usually have a shortage of resources to manage and take account of new demands raised by management system requirements, especially during implementation. So the next section of this article will present clustering as an alternative way of helping small companies to overcome such barriers.

\subsection{Clustering}

There is consensus that industrial clustering is crucial to the economic development of a region or even a country $[16,45,46]$. Many authors claim that such an environment can boost the growth and competitiveness of enterprises, especially small businesses [21, 22, $23,47]$. The benefits of industrial clustering can be explained by means of external economies - the cost-saving benefits of locating a company close to external resources such as skilled labor, specialised training, research institutions, etc. [48]. Besides external economies, small businesses in industrial clusters may gain competitive advantage through inter-firm relationships with other small businesses [22], through supply relationships with larger firms [47], and through joint actions enabled by collaboration among companies [21]. The term 'collective efficiency' refers to the competitive advantage derived from local external economies as well as joint actions [21]. The management of joint actions raises the need for a coordinator or a governance agency to encourage companies, educational institutions, consultants, training providers, and trade associations to collaborate to achieve the intended objectives [18, 49]. The literature reports several studies that emphasise the need to promote joint actions and improvement initiatives [18, 50,51,52, 53]. However, these studies do not discuss specific actions - such as how a governance agency can implement a particular joint action, especially in quality and safety management, which is the purpose of this paper. So small companies within a cluster can benefit from a governance agency's initiatives to provide consultancy and guidance to assist in implementing, auditing, and maintaining management systems, as described later in this article.

According to the literature reviewed above, the research project described in this article was motivated by the following question: How should joint action among small firms be promoted in order to implement a quality and safety management system?

\section{RESEARCH METHODOLOGY}

This research presents aspects of the practical application of recognised concepts (quality management and industrial clusters). An application case often faces unstructured problems that cannot be modelled but must be managed [54]. Thus traditional techniques of production and operations management, such as simulation and mathematical modelling, are unlikely to be the main methods for research in those situations [54]. According to Westbrook, alternative methods, such as empirical research (surveys and case research), theory building, and action research [54], could be used in those situations. 
In cases where intervention is one of the research phases, action research is a method that can be used. According to Reason and Bradbury [55], action research is "a participatory, democratic process concerned with developing practical knowing in the pursuit of worthwhile human purposes, grounded in a participatory worldview which we believe is emerging at this historical moment. It seeks to bring together action and reflection, theory and practice, in participation with others, in the pursuit of practical solutions to issues of pressing concern to people, and more generally the flourishing of individual persons and their communities". In comparison with more conventional research methods, action research approaches are more participatory; create space for learning and reflexivity; are less extractive; support downward accountability; and can cope with complexity [56].

On the other hand, several researchers have criticised the action research method. First, the localism characteristic of action research creates difficulties in extending conclusions beyond the local context [57]. Consequently, validation and generalisation are not easily achieved in action research [58]. Nevertheless, action researchers should explain accurately their approach and its application, bearing in mind that their research will be evaluated in part by its ability to explain practice [59]. Second, action researchers need to present their inferences, attributions, opinions, and viewpoints as open to testing and critique [58]. Finally, a serious criticism brands action research as "consulting masquerading as research" [58]. The clarity of purpose of an exercise in action research is therefore fundamental for avoiding this kind of critique.

Popplewell and Hayman [56] discuss the importance of establishing validity in action research. Actions researchers can seek validity by making a distinction between internal and external validity. Cross-check findings through triangulation is a tool that can be used for achieving internal validity. On the other hand, external validity can be established by means of validation meetings (regular formal meetings with a group of external actors).

Another important issue about action research is that it depends on the experience of the researcher. A key value shared by actions researchers is the respect for people's knowledge and their ability to understand and address the issues confronting them and their communities [57]. Brydon-Miller et al. [57] argue that working collaboratively with others leads not only to community and organisational changes, but also to personal changes in the action researcher. As actions researchers reflect on their experiences, they acknowledge being profoundly transformed by those experiences.

Westbrook [54] presents some practical rules for conducting action research in production and operations management. For these authors, the research process itself needs to be proactively managed; and the quality of the results may depend as much on research project management as on research design or results analysis. Examples of such rules include: do not prespecify the solution; seek multiple viewpoints; do not prevent yourself from pursuing lines of investigation you did not foresee; be sure that the company (managers) checks your write-ups; prefer data to opinion, but remember that opinions are also data; consider that only the principal researcher(s) will usually have sufficient grasp of the whole situation; and give some thought to the right frequency of site visits.

Taking into account many of the previous considerations, we decided to use the action research method. We considered that it would be the appropriate one to use, since our project presented the following characteristics:

- $\quad$ The project proposed a practical implementation of recognised theories;

- The project carried out participative joint actions between the researchers and the staff of the local enterprises;

- The project was conducted by a research team with considerable experience in quality management system implementation and industrial clusters coordination. 
Apart from the practical contribution of this project to the particular cluster, from the academic's perspective this paper presents a proposition and a discussion on joint actions to increase the collective efficiency of a cluster.

The research process adopted for conducting this study was divided into two phases. The principal aim of the first phase was to review the literature on management system integration and industrial clustering. The benefits and difficulties of management system implementation and maintenance were also discussed. The review of the literature, presented in section 2, allowed the identification of important recommendations regarding system integration as well as joint action in clusters, which served as a basis for the research phases that followed. In the second phase, the main objective was to develop the proposal through an empirical study. The general recommendations of action research [58] were adopted to go through the planning, implementation, and evaluation steps. These are detailed in section 4, which presents the research project developed in the Brazilian metalmechanicalal cluster. The paper ends with a discussion of the results of the research project, highlighting benefits and difficulties of the proposed programme as well as further actions required to sustain it.

\section{PLANNING AND IMPLEMENTATION OF THE CERTIFICATION PROGRAMME}

\subsection{Research context}

Data from the Brazilian Institute of Geography and Statistics [60] shows that there are 536 companies in the metal-mechanical cluster of Sertaozinho, in the State of São Paulo, employing about 15,000 people. Around $90 \%$ of these companies manufacture equipment or equipment components used in the production processes of sugar-cane, ethanol, and energy generation, as well as equipment used in the preparation of soil and for planting, cleaning, fertilising, harvesting, and transporting the sugar-cane. About 98 per cent of the companies in this value chain are small metal-mechanical companies with manufacturing processes that usually involve metal cutting, welding, and other hazardous operations. Despite their great need to prevent nonconformities and to control $\mathrm{OH} \& S$ risks in the order fulfilment process, they do not have such competences, and have difficulty implementing management systems.

In this context, the local association of entrepreneurs, CEISE (the main governance agency of cluster initiatives), decided to participate in an initiative in partnership with researchers to develop a programme in quality and OH\&S management. CEISE's motivation derived from the demands of its associates that it assist the companies in their efforts to reduce inefficiencies and to improve quality and $\mathrm{OH} \& S$. The programme consists of assisting the companies, in a joint action with a group of companies, to implement and audit an integrated quality and $O H \& S$ system. The aim is to certify companies that, after the auditing process, have been proved to possess an effective integrated management system. Certification is given by CEISE, and is publicised in the cluster area by means of a 'seal of quality'.

The final goals of this programme are to spread the quality culture and to improve the competence of the small companies in the cluster in managing quality and $\mathrm{OH} \& \mathrm{~S}$ so as to reduce nonconformities, occupational and safety incidents and inefficiencies of all sorts, and to improve competitiveness. The objective is not to replace ISO 9001 or OHSAS 18001 certification. On the contrary, an affordable certification programme can be taken as a first step towards ISO certifications.

\subsection{Research project management and organisational structure}

Based on the action research methodology, the project started by defining the teams of people involved in it. Figure 1 illustrates the organisation, roles, and responsibilities of the research project participants. The executive committee was set up to act strategically, helping to disseminate the project to the cluster and thinking of a permanent programme. It was composed of a member of the main governance body (CEISE), two members on behalf 
of the main companies within the cluster, a local consultant, and the project coordinator. The project management team, responsible for assuring project planning and execution, consisted of the project manager, a student, and one management assistant from the cluster governance agency. The technical committee, formed by a technical consultant, an MSc student, and four undergraduate students, was responsible for training, development of basic procedures, and implementation guidance. Finally, one employee from each company participating in the project was responsible for coordinating the management system as well as facilitating the implementation process in their respective companies. Such an organisational structure sought to follow the recommendations of Popplewell and Hayman [56] in order to ensure internal and external validity.

\begin{tabular}{|c|c|c|c|c|}
\hline & Executive Committee & $\begin{array}{l}\text { Project Management } \\
\text { Team }\end{array}$ & Technical Team & SMEs \\
\hline Roles & $\begin{array}{l}\text {-Define strategic directions } \\
\text {-Disseminate the project to } \\
\text { the local community } \\
\text {-Think of a permanent } \\
\text { program }\end{array}$ & $\begin{array}{l}\text { - Plan activities } \\
\text { - Assure that activities will } \\
\text { occur rnside limits of time } \\
\text { and resources as planned }\end{array}$ & $\begin{array}{l}\text { - Develop procedures } \\
\text { - Training } \\
\text { Implementation guidance }\end{array}$ & $\begin{array}{l}\text { - Facilitation } \\
\text { - Involvement } \\
\text { - Commitment }\end{array}$ \\
\hline Project coordinator & 1 & & & \\
\hline Project manager & & 1 & & \\
\hline MSc student & & & 1 & \\
\hline Undergraduate students & & 1 & 4 & \\
\hline $\begin{array}{c}\text { Cluster Governance } \\
\text { Agency -General Manager }\end{array}$ & 1 & & & \\
\hline $\begin{array}{l}\text { Cluster Governance Agency } \\
\text { Managing assistant }\end{array}$ & & 1 & & \\
\hline $\begin{array}{l}\text { Cluster Governance Agency } \\
\text { Technical Consultant }\end{array}$ & & & 1 & \\
\hline $\begin{array}{l}\text { Member on behalf of } \\
\text { major local companies }\end{array}$ & 2 & & & \\
\hline $\begin{array}{l}\text { Regional Actors - Local } \\
\text { Consultants }\end{array}$ & 1 & & & \\
\hline $\begin{array}{l}\text { SMEs Participants } \\
\text { (Facilitators) }\end{array}$ & & & & 9 \\
\hline
\end{tabular}

Figure 1: Roles, responsibilities, and number of research project participants

After some meetings at CEISE's office, in which the objective and initial plan of activities of the project were presented, a group of nine companies interested in taking part of the project was established. Follow-up of the research project was made using the project management concepts of the PMBOK [61], such as scope, time, communication, and risk management.

\subsection{Implementation planning}

This phase started by understanding particular companies' needs in regard to quality and safety. Eight of the companies taking part in the project manufacture metal-mechanicalal equipment or components mostly for sugar-cane and ethanol plants. One company produces automation equipment, also for sugar-cane and ethanol plants. Table 1 presents a brief description of the companies. For each company, the team identified the requirements related to product quality of conformance and other customer requirements related to order processing and delivery. This initial activity helped the companies to express in detail customer requirements and other related needs.

In this phase, the main objectives were to define the requirements of the management system and the general procedure to implement it in the companies. Table 2 presents the management criteria defined for the integrated system based on quality (ISO9001:2008) [24] and occupational health and safety (OHSAS18001:2007) [28] systems. 
Table 1: Companies taking part in the research project

\begin{tabular}{|c|c|c|}
\hline Company & Main activity & No of employees \\
\hline $\bar{A}$ & $\begin{array}{l}\text { Equipment automation. Main products: electronic control for } \\
\text { steam turbine, software, gateways. }\end{array}$ & 70 \\
\hline B & $\begin{array}{l}\text { Metal-mechanical equipment manufacturing. Main products: } \\
\text { rotary filters, fans. }\end{array}$ & 48 \\
\hline $\bar{C}$ & $\begin{array}{l}\text { Metal-mechanical equipment manufacturing. Main products: filters, } \\
\text { fans, tanks. }\end{array}$ & 30 \\
\hline $\mathrm{D}$ & $\begin{array}{l}\text { Fibre materials manufacturer. Main products: tanks and tubes } \\
\text { and service provider. }\end{array}$ & 54 \\
\hline $\mathrm{E}$ & $\begin{array}{l}\text { Metal-mechanical equipment manufacturing and service } \\
\text { provider. Main products: pumps. }\end{array}$ & 28 \\
\hline $\mathrm{F}$ & Foundry. Main products: metal casting components. & 120 \\
\hline G & $\begin{array}{l}\text { Metal-mechanical equipment manufacturing. Main products: } \\
\text { crushers. }\end{array}$ & 25 \\
\hline $\mathrm{H}$ & $\begin{array}{lcll}\text { Metal-mechanical equipment } & \text { manufacturing } & \text { and } \\
\text { maintenance. Main products: seals. } & & \\
\end{array}$ & 23 \\
\hline $\mathrm{I}$ & $\begin{array}{l}\text { Metal-mechanical equipment } \quad \text { manufacturing } \text { and } \\
\text { maintenance. Main products: shafts, gears transmission box. }\end{array}$ & 160 \\
\hline
\end{tabular}

Table 2: Integrated management system criteria

\begin{tabular}{|c|c|c|}
\hline Integrated management system criteria & $\begin{array}{l}\text { IS09001:2008 } \\
\text { Requirement }\end{array}$ & $\begin{array}{l}\text { OHSAS18001:2007 } \\
\text { Requirement }\end{array}$ \\
\hline \multicolumn{3}{|l|}{1 Planning } \\
\hline 1.1 Integrated management system & $4.1 ; 5.5 .2$ & 4.1 \\
\hline 1.2 Communication & $\begin{array}{c}4.2 .1 ; 4.2 .2 ; 4.2 .3 ; 4.2 .4 ; \\
\text { 5.5.1; 5.5.3 }\end{array}$ & $\begin{array}{c}\text { 4.4.1; 4.4.3.1; 4.4.4; } \\
\text { 4.4.5; 4.5.4 }\end{array}$ \\
\hline 1.3 Quality and $\mathrm{OH} \& S$ planning & $5.3 ; 5.4 .1 ; 6.3 ; 6.4$ & 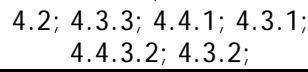 \\
\hline \multicolumn{3}{|l|}{2 Product realisation and human resources } \\
\hline 2.1 Customer & 7.2.1; 7.2.2; 7.2.3; 7.5.4; & 4.4.3; 4.4.6; \\
\hline 2.2 Processes & $\begin{array}{c}\text { 7.1; 7.3; 7.4.1; 7.4.2; 7.4.3; } \\
\text { 7.5.1; 7.5.3; 7.5.5; 7.6 }\end{array}$ & $4.4 .6 ; 4.5 .1$ \\
\hline $\begin{array}{l}\text { 2.3 Human resource, occupational } \\
\text { health and safety }\end{array}$ & 6.2.1;6.2.2; & $4.4 .2 ; 4.4 .7$ \\
\hline \multicolumn{3}{|l|}{3 Measurement } \\
\hline 3. 1 Customer satisfaction & 8.2 .1 & \\
\hline $\begin{array}{l}\text { 3. } 2 \text { Monitoring and measurement of } \\
\text { product } \& \text { process }\end{array}$ & $8.2 .3 ; 8.3$ & \\
\hline 3. 3 Performance in $\mathrm{OH} \& \mathrm{~S}$ & & $4.5 .1 ; 4.5 .2 ; 4.5 .3$ \\
\hline 3.4 Internal audit & 8.2 .2 & 4.5 .5 \\
\hline \multicolumn{3}{|l|}{4 Review and improvement } \\
\hline 4. 1 Management review & 5.6 & 4.6 \\
\hline 4. 2 Continuous improvement & 8.5.2; 8.5. & 4.5.3.2 \\
\hline
\end{tabular}

The development of management procedures to support the system requirements was planned as a three-step process that included the following activities:

a) Training on the system criteria and standard requirements;

b) Designing and implementing operational procedures and records;

c) Verification of progress.

Figure 2 illustrates the implementation process. The purpose is to implement and evaluate the system gradually, requirement by requirement, and to finalise it with an external audit. Once implementation is complete, the last phase in the certification programme is auditing the management system. Based on the auditing recommendations, further work on implementation might be required before certification. The feedback loop in Figure 2 illustrates this idea. 


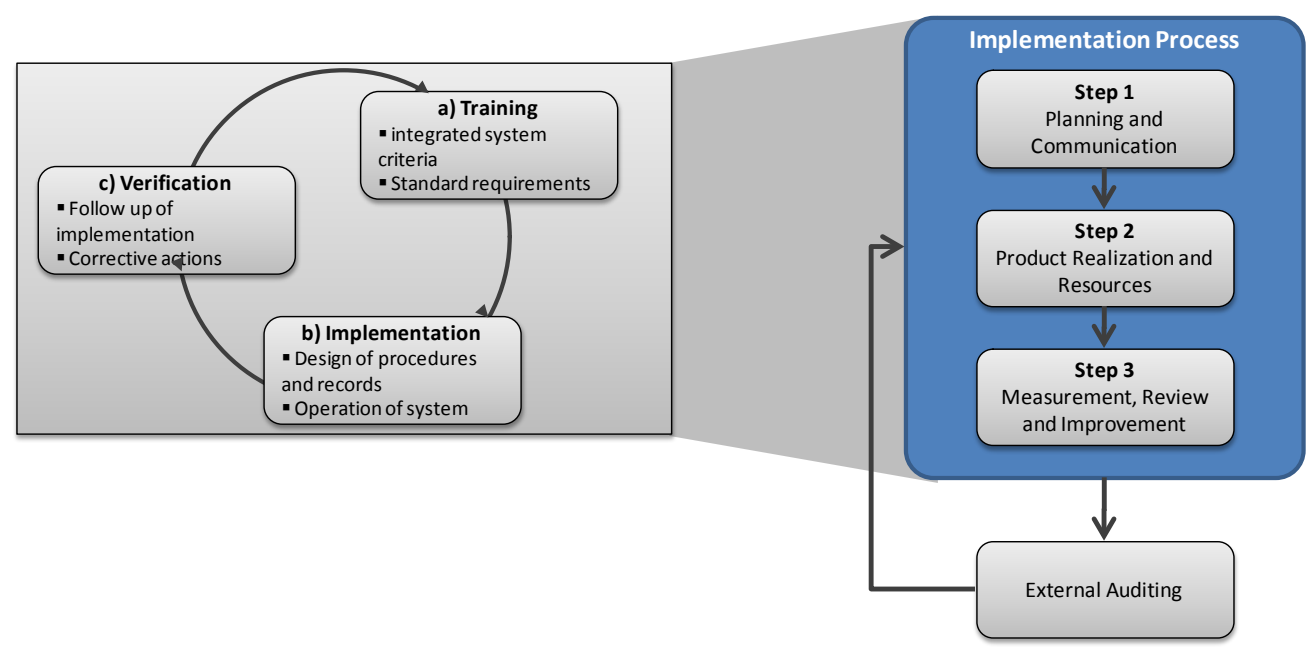

Figure 2: Implementation process of integrated management system

\subsection{Implementation phase}

The implementation phase in each company started in November 2009, after detailing planning of the action and the timetable. The training sessions were held at CEISE's office from November 2009 to April 2010, gathering the companies' representatives. After training, representatives from each company were helped by the project technical committee to implement the system. After training and implementation of each set of requirements, the programme technical coordinator was responsible for checking how far the companies were evolving in the implementation process, as illustrated by the implementation cycle in Figure 2. Of the nine companies that started implementation, four gave up during the process. Four out of the five remaining companies that had started implementation in November 2009 were able to complete implementation in May 2010. External auditing was carried out in J une and J uly 2010. After reviewing the system based on external auditing, two companies were evaluated as qualified and entitled to receive the Seal of Quality without maj or changes in their quality and safety system. The remaining two companies were evaluated by the auditing team as needing further implementation of their system.

\section{ANALYSIS OF RESULTS AND CONCLUDING REMARKS}

During the implementation phases, the researchers participated effectively in the project, collaborating with the cluster governance agency in the process of defining the certification programme, and guiding the companies through the steps of implementation and the evaluation process. Following up the project and interacting with the team enabled the researchers to reflect on the proposed certification programme as action was happening.

One of the main benefits of this certification programme to the companies within the cluster is the assistance given them in implementing and maintaining a management system. For small companies, which usually have limited resources, such an initiative can avoid the extra costs of training, consultancy, and certification. Two of the companies that were not able to finish the implementation, despite being motivated by the initial proposal, encountered unforeseen financial difficulties during the process and had to give up implementation.

But the shortage of resources is not the only impediment that small companies face when implementing and maintaining a management system. As mentioned in section 2.3, there are some intra-organisation factors that are crucial for companies of any size if they are to succeed and benefit from implementing and maintaining quality and other management systems. Likewise, the certification programme proposed here also requires the full 
commitment of participating companies to the implementation and maintenance of the system, involvement and training of the workforce, sustainable internal audits, a management review of the management system, and corrective action. These are the requirements of the ISO 9000 systems; not doing them means non-conformance. The external support for system implementation and maintenance provided by the cluster governance body will be useless if the companies do not fully engage themselves in the quality and safety management. Following up the implementation phase and observing the participating companies, it is easy to realise that most of the companies did not prove to be prepared for it, either because of the owners' and senior managers' lack of commitment, or the workforce's lack of involvement. For this reason, a recommendation arising from this experience is that external support should provide more information to ensure the participation and commitment of companies in the programme. In other words, the external support should gather data on the companies' readiness before implementation, and ensure that these issues exist as a prerequisite for participation. The data, in the form of the above-mentioned problems, must now be analysed so that action planning can take place to aid the next implementation.

Sustainability of the proposed certification programme certainly depends on an unequivocal commitment of companies to quality and safety management. At the same time, the cluster governance bodies and the main client companies within the cluster play an important role in changing the values and beliefs of small companies within the cluster. Recognition of the quality seal by the main clients (sugar-cane and ethanol industries) and by the community is a fundamental step in emphasising the importance of quality and safety management. Reports that some of the companies participating in the pilot application were able to close a deal after showing the client their initiative in implementing a management system may help to demonstrate the significance of such a programme. Publicising the certification programme and showing the potential benefits of certification in quality and safety management is therefore a very good way of promoting this cultural change.

While publicising the programme is important, it is not enough. The governance agency (CEISE) still has a lot of work to do to gain the trust of the companies in the cluster. Running the programme on a regular basis includes offering training and consultancy to a small business during the implementation process, maintaining a pool of auditors, and providing services of auditing and re-auditing the system periodically. It requires a sense of ownership of the programme by the local agency, as well as special attention to key factors such as:

- Establishment of a local structure and infrastructure to support the programme;

- Clear definition of roles and responsibilities in order to manage and operate the programme;

- Involvement of local professionals in the programme;

- Communication, training, and qualification in required capacities;

- Professionalism and transparency in the implementation and auditing processes.

Analysis of the results of this first research cycle of application demonstrated the need to develop a more complete documentation of the certification programme in the form of a manual, detailing the activities, rules, and responsibilities of all members. Implementation of the integrated management system in the companies should be carried out by their employees, with training and technical assistance from a technical committee of the governance agency; periodic auditing should be conducted by external auditors with the coordination of the technical committee. For the companies in the cluster, participation in the programme implies obeying some rules and accepting roles and responsibilities. For the governance agency, represented by the technical committee, its main responsibilities include publicising the programme, forming a group of companies, managing the process of implementation, providing training and technical guidance, and periodically auditing the companies to check whether they have an effective management system in place. From our experience in running the first research cycle, Figure 3 illustrates a proposal of the main elements and steps as well as the organisation of the programme. Implementation and 
auditing are based on the integrated management system model and processes presented earlier in Table 2 and Figure 2 respectively.

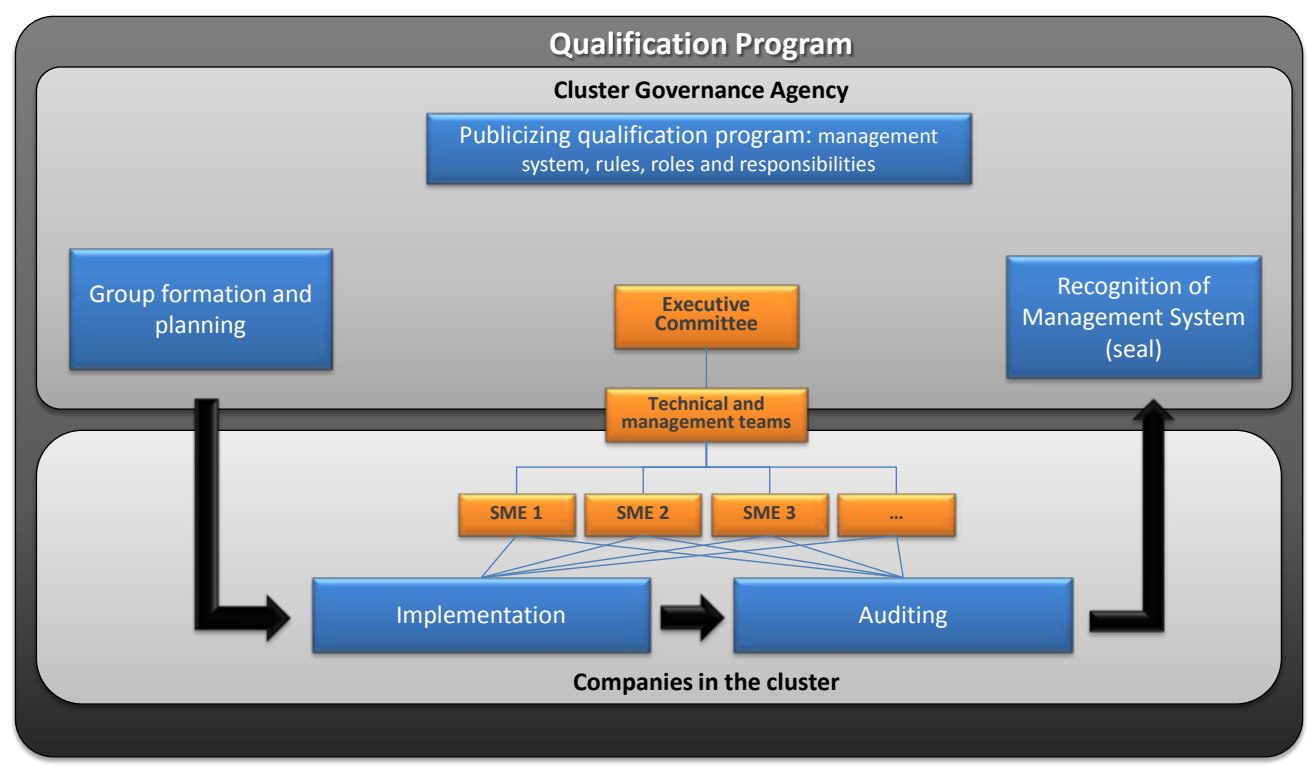

Figure 3: Programme for certification in quality and safety management

Following this first application cycle, a joint action initiative led by the governance agency initiated the revised certification programme with a second group of five companies.

To sum up: despite all the obstacles discussed here, the proposal presented in this paper can help to reduce the difficulties faced by small businesses within the cluster in implementing and maintaining management systems - and, in the long run, foster a culture of quality and safety management. Equally important, it can contribute positively to organising and consolidating cooperation and improvement management within the cluster.

\section{ACKNOWLEDGEMENTS}

To the Brazilian National Council for Research (CNPq) for supporting this project.

To the anonymous reviewers for their valuable contribution to this article.

\section{REFERENCES}

[1] ISO. 2011. The ISO Survey of Management System Standard Certifications - 2011. http:// www. iso. org/ iso/ home/ standards/ certification/ iso-survey. htm.

[2] Gotzamani K., Tsiotras, G.D., Nicolaou, M., Nicolaides, A. \& Hadjiadamou, V. 2007. The contribution to excellence of ISO9001: The case of certified organizations in Cyprus. The TQM Magazine, 19(5), 388-402.

[3] Singh, P., Feng, M. \& Smith, A. 2006. IS09000 series of standards: Comparison of manufacturing and service organizations. International J ournal of Quality \& Reliability Management, 23(2), 123142.

[4] Yeung, G. \& Mok, V. 2005. What are the impacts of implementing ISOs on the competitiveness of manufacturing industry in China? J ournal of World Business, 40, 139-157.

[5] Muñiz, B.F., Péon, J.M. M. \& Ordáz, C.J.V. 2009. Relation between occupational safety and firm performance, Safety Science, 47, 980-991.

[6] Bottani, E., Monica, L. \& Vignali, G. 2009. Safety management system: Performance differences between adopters and non-adopters, Safety Science, 47, 155-162.

[7] OHSAS Project Group. 2009. Results of the survey into the availability of OH\&S Standards and Certificates, up until 2009-12-31. http:// ohsas18001expert.com/ wp-content/ uploads/ 2011/ 05/ 2009-OHSAS-Certificates-Survey-Results. pdf.

[8] Wilkinson, G. \& Dale, B. 1999. Integrated management systems - an examination of the concept 
and theory. The TQM Magazine, 11(2), 95-104.

[9] Zutshi, A. \& Sohal, A.S. 2005. Integrated management system - The experiences of three Australian organisations. J ournal of Manufacturing Technology Management, 16, 211-232.

[10] J orgensen, T.H., Remmen, A. \& Mellado, M.D. 2006. Integrated management systems - three different levels of integration. J ournal of Cleaner Production, 14, 713-722.

[11] Zeng, S.X., Shi, J.J. \& Lou, G.X. 2007. A synergetic model for implementing an integrated management system - an empirical study in China. J ournal of Cleaner Production, 15, 1760-1767.

[12] J onker, J . \& Karapetrovic, S. 2004. System thinking for the integration of management systems. Business Process Management J ournal, 10(6), 608-615.

[13] Poksinska, B., Eklund, J.A.E. \& Dahlgaard, J.J . 2006. ISO 9001:2000 in small organisations: Lost opportunities, benefits and influencing factors. International Journal of Quality \& Reliability Management, 23/ 5, 490-512.

[14] Brand, R.P., du Preez, N.D. \& Schutte, C. 2007. A business framework to network small South African enterprises for sustainability, South African J ournal of Industrial Engineering, 18(2), 187201.

[15] Turner, A. \& O'Neill, C. 2007. Confronting the inevitable: ISO 14001 implementation and the Durban automotive cluster, South African J ournal of Industrial Engineering, 18(2), 1-19.

[16] Porter, M. 1998. Clusters and the new economics of competition, Harvard Business Review, NovDec, 77-90.

[17] Mytelka, L. \& Farinelli, F. 2000. Local clusters, innovation systems and sustained competitiveness. United Nations University, Institute for New Technologies, The Netherlands.

[18] Sölvell, Ö., Lindquist, G. \& Ketels, C. 2003. The cluster initiative greenbook, Stockholm, Bromma tryck AB.

[19] Hanna, V. \& Walsh, K. 2008. Interfirm cooperation among small manufacturing firms, International Small Business J ournal, 26(3), 299-321.

[20] Schmitz, H. \& Nadvi, K. 1999. Clustering and industrialization: introduction, World Development, 27 (9), 1503-14.

[21] UNIDO. 2001. Development of clusters and networks of SMEs. United Nations Industrial Development Organization, Vienna.

[22] Karaev, A., Koh, S. \& Szamosi, L. 2007. The cluster approach and SME competitiveness: A review, J ournal of Manufacturing Technology Management, 18(7), 818-835.

[23] Capó-Vicedo, J., Expósito-Langa, M. \& Molina-Morales, F. 2008. Improving SME competitiveness reinforcing interorganisational networks in industrial clusters. International Entrepreneurship and Management J ournal, 4, 147-169.

[24] ISO. 2008. ISO9001:2008 - Quality Management System - Requirements. International Organization for Standardization.

[25] Koc, T. 2007. The impact of ISO9000 quality management systems on manufacturing. J ournal of Materials Processing Technology, 186, 207-213.

[26] Singh, P.J. 2008. Empirical assessment of 1509000 related management practices and performance relationships, International J ournal of Production Economics, 113, 40-59.

[27] Sampaio, P., Saraiva, P. \& Rodrigues, A.G. 2010. A classification model for prediction of certification motivations from the contents of ISO9001 audit reports. Total Quality Management and Business Excellence, 21(12), 1279-1298.

[28] OHSAS. 2007. OHSAS18001:2007 Occupational Health and Safety Management Systems Requirements. Occupational Health and Safety Assessment Series.

[29] ISO. 2004. ISO14001:2004 Environmental management systems - Requirements with guidance for use. International Organization for Standardization.

[30] Wilkinson, G. \& Dale, B.G. 2001. Integrated management systems: A model based on a total quality approach. Managing Service in Quality, 11(5), 318-330.

[31] Labodova, A. 2004. Implementing integrated management systems using risk analysis based approach. J ournal of Cleaner Production, 12, 571-580.

[32] Martínez-Costa, M., Martínez-Lorente, A.R. \& Choi, T. Y. 2008. Simultaneous consideration of TQM and ISO 9000 on performance and motivation: An empirical study of Spanish companies. International J ournal of Production Economics, 113, 23-39.

[33] Casadesús, M. \& Karapetrovic, S. 2005a. Has ISO9000 lost some of its lustre? A longitudinal impact study. International J ournal of Operations and Production management, 25(6), 580-596.

[34] Casadesús, M. \& Karapetrovic, S. 2005b. The erosion of ISO9000 benefits: A temporal study. International J ournal of Quality and Reliability Management, 22(2), 120-136.

[35] Casadesús, M. \& Karapetrovic, S. 2005c. An empirical study of the benefits and costs of ISO9001:2000 compared to ISO9001/2/3:1994. Total Quality Management and BusinesS Excellence, 16(1), 105-120.

[36] Casadesús, M. \& Karapetrovic, S. 2010. What happened to the ISO9000 lustre? An eight-year study. Total Quality Management and Business Excellence, 21(3), 245-267.

[37] Singh, P. \& Mansour-Nahra, P. 2006. ISO9000 in the public sector: A successful case from Australia. The TQM Magazine, 18(2), 131-142.

[38] Chang, D.S. \& Lo, L.K. 2005. Measuring the relative efficiency of a firm's ability to achieve 
organizational benefits after ISO certification. Total Quality Management and BusinesS Excellence, 16(1), 57-69.

[39] Lima, M.A.M., Resende, M. \& Hasenclever, L. 2000. Quality certification and performance of Brazilian firms: An empirical study. International Journal of Production Economics, 66(2), 143147.

[40] Benner, M.J . \& Veloso, F.M. 2008. ISO 9000 practices and financial performance: A technology coherence perspective. J ournal of Operations Management, 26 (2008) 611-629.

[41] Celik, M. 2009. Designing of integrated quality and safety management system (IQSMS) for shipping operations. Safety Science, 47, 569-577.

[42] Pheng, L.S. \& Pong, C.Y. 2003. Integrating ISO9001 and OHSAS 18001 for construction. J ournal of Construction Engineering and Management, May/J une, 338-347.

[43] Briscoe, J.A., Fawcett, S.E. \& Todd, R.H. 2005. The implementation and impact of ISO9000 among small manufacturing enterprises. J ournal of Small Business Management. 43(3), 309-330.

[44] Wahid, R.A., Corner, J. \& Tan, P.L. 2011. ISO maintenance in service organizations: Tales from two companies. International J ournal of Quality and Reliability, 28(7), 735-757.

[45] Krugman, P. 1998. What's new about the new economic geography? Oxford Review of Economic Policy, 14 (2).

[46] Schmitz, H. 1999. Collective efficiency and increasing returns. Cambridge J ournal of Economics, 24(4), 465-483.

[47] Humphrey, J. \& Schmitz, H. 1998. Trust and inter-firm relations in developing and transaction economies. The J ournal of Development Studies, 34(4), 32-61.

[48] Plummer, P. \& Taylor, M. 2001. Theories of local economic growth (part 1): Concepts, models, and measurement. Environment and Planning A, 33(2), 219-236.

[49] Bititci, U., Martinez, V., Albores, P. \& Parung, J. 2004. Creating and managing value in collaborative networks. International J ournal of Physical Distribution and Logistics Management, $34(3 / 4), 251-268$.

[50] DTI. 2005. A practical guide to cluster development. British Department of Trade and Industry, 2005.

[51] Fromhold-Eisebith, M. \& Eisebith, G. 2005. How to institutionalize innovative clusters? Comparing explicit top-down and implicit bottom-up approaches. Research policy, 34(8), 12501268.

[52] Carpinetti, L.C.R., Galdamez, E.V.C. \& Gerolamo, M.C. 2008. A measurement system for managing performance of industrial clusters: A conceptual model and research cases. International J ournal of Productivity and Performance Management, 57(5), 405-419.

[53] Aramburu, X. \& Querejeta, M.J.A. 2009. Cluster policy governance: Towards a multi-level approach? The case of the Basque contry (Spain). In: Proceedings of the Conference on Developments in Economic Theory and Policy. Bilbao.

[54] Westbrook, R. 1995. Action research: A new paradigm for research in production and operations management. International J ournal of Operations \& Production Management, 15/ 12, 6-20.

[55] Reason, P. \& Bradbury, H. (eds). 2001. Handbook of action research: Participative inquiry and practice. London: Sage Publications.

[56] Popplewell, R. \& Hayman, R. 2012. Where, how and why are action research approaches used by international development non-governmental organisations? INTRAC - International NGO Training and Research Centre, Briefing Paper 32.

[57] Brydon-Miller, M., Greenwood, D. \& Maguire, P. 2003. Why action research? Action Research, 1(1), 9-28.

[58] Coughlan, P. \& Coghlan, D. 2002. Action research for operations management. International J ournal of Operations \& Production Management, 22/ 2, 220-240.

[59] Avison, D., Lau, F., Myers, M. \& Nielsen, P.A. 1999. Action research: To make academic research relevant, researchers should try out their theories with practitioners in real situations and real organizations. Communications of the ACM, 42/1, J anuary.

[60] IBGE. 2009. Business directory. Brazilian Institute of Geography and Statistics. Rio de J aneiro.

[61] Project Management Institute (PMI). 2008. A guide to the project management body of knowledge. Pennsylvania, EUA: Four Campus Boulevard. 